\title{
LOW OXYGENATION STATUS INCREASES NAUSEA-VOMITING INCIDENCE IN HEMODIALYSIS PATIENTS
}

\author{
(Status Oxygenasi Rendah Meningkatkan Kejadian Nausea-Vomittrik Pada Pasien \\ Dengan Hemodialisis)
}

\author{
Cornelia D.Y Nekada, Mohamad Judha \\ E-mail: cornelia.nekada@gmail.com
}

\begin{abstract}
ABSTRAK
Pendahuluan: Data RISKESDAS (2013), menyebutkan kejadian gagal ginjal kronis di Indonesia meningkat, khususnya di DIY dengan prevalensi gagal ginjal kronis sebesar 0,3\%. Apabila pasien gagal ginjal kronis memasuki tahap End Stage Renal Disease (ESRD), ginjal membutuhkan terapi pengganti untuk membantu fungsinya. Terapi ini disebut dengan Continuous Renal Replacement Therapi (CRRT) atau hemodialisis (HD). Terapi hemodialis dapat berdampak pada ketidakseimbangan oksihemoglobin dalam darah. Pasien yang menjalani hemodialisis dapat mengalami keluhan mualmuntah intradialisis. Tujuan penelitian ini untuk mengidentifikasi adakah hubungan antara status oksigenasi predialisis melalui pemeriksaan saturasi oksigen $\left(\mathrm{SpO}_{2}\right)$ dan respiratory rate $(\mathrm{RR})$ terhadap kejadian mual-muntah intradialisis. Metode: Penelitian ini merupakan study komparasi dengan desain analitik cross sectional. Penelitian ini dilakukan di ruang hemodialisis RSUD Panembahan Senopati Bantul. Subyek penelitian ini diambil secara total sampling, dengan tetap memperhatikan etika penelitian. Keseluruhan subyek penelitian ini adalah 183 responden. Peneliti mengukur saturasi oksigen dan RR pasien predialisis dan mengkaji keluhan mual muntah intradialisis. Hasil: Hasil analisa Fisher exact penelitian ini menunjukkan nilai $p$ sebesar 0,000 baik pada analisa bivariat saturasi oksigen terhadap kejadian mual muntah maupun pada analisa bivariat respiratory rate terhadap kejadian mual muntah. Analisis multivariat menggunakan regresi logistic menunjukkan bahwa OR saturasi oksigen adalah 73,57, ini memiliki makna bahwa pada pengukuran saturasi oksigen yang tidak normal memiliki peluang tujuh puluh tiga kali terhadap kejadian mual muntah, bila dibandingkan dengan pasien yang memiliki saturasi oksigen yang normal. Diskusi: Mual muntah intradialisis salah satu penyebabnya adalah ketidakseimbangan oksihemoglobin. Kesiapan status oksigenasi predialisis perlu diperhatihan, sehingga keluhan mual dan muntah dapat diantipasi sejak awal.
\end{abstract}

Kata Kunci: Predialisis, Oksigenasi, Mual Muntah, Intradialisis

\begin{abstract}
Introduction: Data from Indonesia Basic Health Research (2013) states that the chronic renal failure in Indonesia is increasing, especially in Yogyakarta with the prevalence of chronic renal failure of 0,3\%. If the patients of chronic renal failure are in End Stage Renal Disease (ESRD), the kidney needs replacement therapy to help its function. This therapy is called Continuous Renal Replacement Therapy (CRRT) or Hemodialysis (HD). Hemodialysis therapy may influence to the imbalance of oxyhemoglobin in the blood. Patients undergoing hemodialysis may experience intradialytic nausea and vomiting. The objective of this study is to identify whether there is a relationship between pre-dialysis oxygenation status through oxygen saturation $\left(\mathrm{SpO}_{2}\right)$ and respiratory rate $(\mathrm{RR})$ examination and the intradialytic nausea-vomiting occurrence. Method: This research is a comparative research with the analytical cross sectional design. This research was conducted in hemodialysis room in Public Hospital of Panembahan Senopati Bantul. The subject of the research was taken using total sampling, by paying attention to research ethics. The total research subjects are 183 respondents. The researchers measured the oxygen saturation and patients' respiratory rate and examined intradialytic nausea and vomiting complaints. Result: The analysis result of Fisher's exact in this research shows $p$ value of 0,000 both in the bivariate analysis of oxygen saturation to nausea and vomiting occurrence and in the bivariate analysis of the respiratory rate to nausea and vomiting occurrence. The multivariate analysis employing logistic regression shows that the OR of oxygen saturation is 73,57, this means that the measurement of the abnormal oxygen saturation has the chance of seventy-three times more to nausea and vomiting occurrence if compared to the patients with normal oxygen saturation. Discussion: Intradialytic nausea and vomiting are one of the causes of the imbalance of oxyhemoglobin. The readiness of pre-dialysis oxygenation status needs to be noticed so that nausea and vomiting complaints can be anticipated earlier.
\end{abstract}

Keywords: Pre-dialysis, Oxygenation, Nausea and Vomiting, Intradialytic

\section{INTRODUCTION}

The data increase of the chronic renal failure patients in Indonesia is relatively high along with age of the patients. The chronic renal failure occurrence in the age group of $35-44$ is of $0,3 \%$, and the highest occurrence is in the age group of more than or equal to 75 years, which is of $0,6 \%$. The prevalence 
of chronic renal failure in Yogyakarta is of 0,3\% (Indonesia Basic Health Research, 2013, 2011). The chronic renal failure disease has five stages, at the end stage or known as End Stage Renal Disease (ESRD) is identified by the decrease of the filtration ability less than $15 \mathrm{ml} / \mathrm{min} / 1,73 \mathrm{~m}^{2}$ (Cirillo, Lombardi, Mele, Marcarelli, \& Bilancio, 2011). End Stage Renal Disease can also cause complications, especially related to morbidity and mortality of the population so that it needs therapy to help the function of the kidney and to prevent morbidity and mortality (Coca, Singanamala, Parikh, 2012). Therapy given to the patients with chronic renal failure can also be in the form of oral medication or other therapies as the replacement of kidney's function. One of the therapies given to the patients with chronic renal failure is CRRT (Continuous Renal Replacement Therapy) or hemodialysis. Hemodialysis therapy of the chronic renal failure is conducted two times a week; all patients must conduct this therapy routinely, if the patients expect no more other complaints due to their condition (Daugirdas, Greene, Rocco, Kaysen, Levin, Depner, 2013) Patients with hemodialysis (HD) are those of critical nursing area with the approach of end of life care. End of life care nursing provides nursing care addressed to the patients diagnosed with terminal illness and needed to conduct therapy for a long time, to lengthen the life expectancy (Chan; Osterman, 2013). A nurse who provides nursing care to the critical patients, especially patients with $\mathrm{HD}$, needs to provide comprehensive care to the pre-dialysis, intra-dialysis, and post-dialysis stages. The comprehensive nursing care can facilitate the adequacy of hemodialysis process. One of the signs that the hemodialysis is adequate is that there is no complication that occurs. (Fall \& Szerlipt, 2010). Ferrario, Moissl, Garzotto, Cruz, Clementi, Brendolan, et al. (2014), suggest that the intradialytic complications that often occur are headaches, nausea and vomiting, intradialytic hypertension and hypotension, muscle cramps, hypothermia, and electrolyte imbalance syndrome. Those complications commonly occur due to the high speed of hemodialysis process (Quick of Blood/QB), the high level of urea creatinine in blood, as well as other physical problems of the patients (Mujais \& Ismail, 2013). From the result of the interview and observation in a prior study conducted by the researcher in Public Hospital of Panembahan Senopati Bantul, the complaint that mostly occurs in hemodialysis process is nausea and vomiting, which is $27 \%$. Rizo, et.al (2012) explains that the response of intradialytic nausea and vomiting is one of neurological gastrointestinal response that may occur due to the hemostatic change during hemodialysis process. The hemostatic change influences to the hemoglobin imbalance that eventually leads to the decrease of oxyhemoglobin level in the blood and perfusion problems to the gastrointestinal (Han, Oh, Hong, Yi, Noh, Lee, et al., 2016).

One of the ways that can be used to anticipate the intradialytic nausea and vomiting is by conducting an examination of pre-dialysis accurately (Hasan, Muqueet, Asadujjaman, Sharmeen, Kabir, Rahman, 2013). From the result of the observation that has been done by the researchers, the pre-dialysis examination that has been done regularly in hemodialysis room in Public Hospital of Panembahan Senopati Bantul includes measurement of the weight, while in the intra-dialysis of the patients, it includes the examination of vital signs and complaints from the patients. This research conducts an examination to the patients who will conduct hemodialysis, focusing on oxygenation status, which is the $\mathrm{SpO}_{2}$ and respiratory rate (RR), as well as examining nausea and vomiting occurrence during the hemodialysis process. This research aims at identifying the relationship of predialysis oxygenation status in the form of $\mathrm{SpO}_{2}$ and respiratory rate to nausea and vomiting occurrence in Public Hospital of Panembahan Senopati Bantul and aims at identifying which variable, $\mathrm{SpO}_{2}$ or $\mathrm{RR}$, is more dominant, to the intradialytic nausea and vomiting occurrence. 


\section{METHOD}

This research is a non-experimental comparative study with analytical cross sectional design (Dharma, 2011). This research takes the sample by using total sampling method but still pays attention to the research ethics. The number of the respondents in this research is 183 respondents, which allows the researchers to conduct an examination of predialysis oxygenation status and intradialytic nausea and vomiting complaints. This research was conducted in hemodialysis room in Public Hospital of Panembahan Senopati Bantul on July 12-14 in 2016. This research employs instruments, which are observation sheets to record the pre-dialysis oxygenation status, in the form of $\mathrm{SpO} 2$ and $\mathrm{RR}$ and intradialytic nausea and vomiting occurrence; portable pulse oximetry to measure $\mathrm{SpO}$; and respiratory rate timer to calculate the breathing frequency in one minute. The research instruments are stated to be valid and reliable through calibration test all data in this research are categorized. The respiratory rate data are presented in ordinal data, stated to be normal if the calculation result using respiratory rate timer shows 12-20 times per minute, and stated to be abnormal if it is under or above that range. The data of oxygen saturation are presented in ordinal data, and stated to be normal if the screen of portable pulse oximetry shows $\geq 95 \%$, and stated to be abnormal if the result is $<95 \%$ (DeLaune \& Ladner, 2011; Yuan, Drost, Mclvor, 2013). The portable pulse oximetry is placed in the extremity with no permanent hemodialysis catheter. The data of intradialytic nausea and vomiting are presented in nominal data, stated as "yes" if the patients experience nausea and vomiting complaints during hemodialysis process, and stated as "no" if the patients do not experience nausea and vomiting complaints during hemodialysis process. The variables are suspected as confounding variables and may cause to the intradialytic nauseavomiting occurrence are age, gender, and hemodialysis period. The bivariate analysis employs Chi Square test, seen in Fisher's exact value. The multivariate analysis employs regression logistic. This research identifies the relationship between $\mathrm{SpO} 2$ and $\mathrm{RR}$ to the nausea-vomiting occurrence. This research also wants to see which is more dominant, either $\mathrm{SpO} 2$ or $\mathrm{RR}$, to the occurrence of intradialytic nausea-vomiting. The research conducted also hold the principle of research ethics which are beneficence, autonomy, anonymity, veracity, justice and written down in informed consent given to the respondents (Dharma, 2011).

\section{RESULT}

Gender with the most respondents is female of $73,8 \%$. The prior study by Syamsiah, Sitorus, \& Nasution (2011) explains that the gender with the most respondents is male of $54,1 \%$ (Table 1). Table 2 shows that the average age of the respondents is 53 years, and that of hemodialysis period is 32 months. Almost all patients have $\mathrm{SpO}_{2}$ with the category of normal $(92,3 \%)$. In this research, $\mathrm{SpO}_{2}$ is measured by using portable pulse oximetry (Table 3).

The Fisher exact analysis result of $\mathrm{SpO}_{2}$ to the nausea-vomiting occurrence obtains the $p$ value of 0,000 , which means that there is a significant relationship between $\mathrm{SpO}_{2}$ and nausea-vomiting occurrence (Table 4). The variables that fulfill the requirements for the multivariate analysis stage are RR and

Table 1. Respondents' Characteristics Based on Gender, Education, and Occupation

\begin{tabular}{lr}
\hline \multicolumn{1}{c}{ Characteristics } & Total n (\%) \\
\hline Gender & \\
Male & $48(26,2)$ \\
Female & $135(73,8)$ \\
Education & \\
Uneducated & $19(10,4)$ \\
Elementary School & $52(28,4)$ \\
Junior High School & $31(16,9)$ \\
Senior High School & $62(33,9)$ \\
College/University & $19(10,4)$ \\
Occupation & \\
Unemployment & $64(35)$ \\
Private Employee & $56(30,6)$ \\
Entrepreneur & $13(7,1)$ \\
Civil Servant & $5(2,7)$ \\
Retired employee & $24(13,1)$ \\
Farmer & $21(11,5)$ \\
Total & $183(100)$ \\
\hline
\end{tabular}


Jurnal INJEC Vol. 2 No. 1 Juni 2017: 21-33

Tab1e 2. Respondents' Characteristics Based on Age and Hemodialysis Period

\begin{tabular}{lccc}
\hline \multicolumn{1}{c}{ Characteristics } & Mean & Minim & Maxim \\
\hline Age* $^{*}$ & 53 & 21 & 83 \\
Hemodialysis Period* & 32 & 3 & 120 \\
\hline
\end{tabular}

*Age in year, Hemodialysis period in months

Table 3. Frequency Distribution Based on Pre-dialysis $\mathrm{SpO}_{2} \& \mathrm{RR}$ and Intradialytic Nausea-Vomiting Occurrence

\begin{tabular}{lc}
\hline \multicolumn{1}{c}{ Conditions } & Total n (\%) \\
\hline $\mathrm{SpO}_{2}$ & \\
Normal & $169(92,3)$ \\
Abnormal & $14(7,7)$ \\
$\mathrm{RR}$ & \\
Normal & $122(66,7)$ \\
Abnormal & $61(33,3)$ \\
Intradialytic Nausea-Vomiting Occurrence & \\
No Nausea-Vomiting & $171(93,4)$ \\
Nausea-Vomiting & $12(6,6)$ \\
Total & $183(100)$ \\
\hline
\end{tabular}

Table 4. Relationship between Pre-dialysis $\mathrm{SpO}_{2} \& \mathrm{RR}$ and Intradialytic Nausea-Vomiting Occurrence

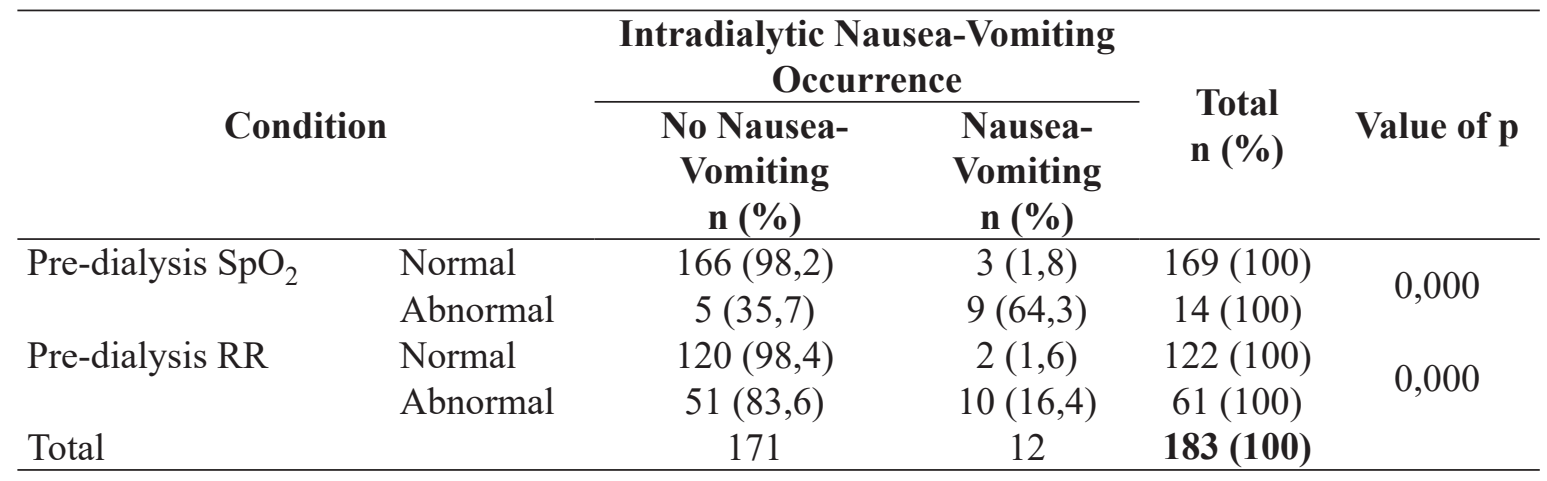

Table 5. Selection Result of Multivariate Candidate Variables with Intradialytic Nausea-Vomiting Occurrence $(\mathrm{N}=183)$

\begin{tabular}{|c|c|}
\hline Multivariate Candidate Variables & $p$ value \\
\hline 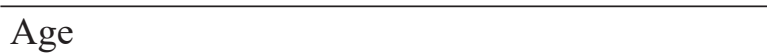 & $0,888^{* *}$ \\
\hline Gender & $0,145^{* *}$ \\
\hline HD period & $0,696^{* *}$ \\
\hline RR & $0,000^{*}$ \\
\hline $\mathrm{SpO}_{2}$ & $0,000 *$ \\
\hline
\end{tabular}

* Variables that fulfill the requirements to do multivariate test must have $\mathrm{p}$ value of $<0,25$

** Variables are stated to have relationship if the $\mathrm{p}$ value $<0,05$. 
Table 6. The Modeling Result of Multivariate Variables Analysis to the Nausea-Vomiting Occurrence

\begin{tabular}{|c|c|c|c|c|c|}
\hline \multirow{2}{*}{ Variable } & \multirow{2}{*}{ B } & \multirow{2}{*}{ p (sig) } & \multirow{2}{*}{$\operatorname{Exp}(B) O R$} & \multicolumn{2}{|c|}{$\operatorname{Exp}($ B) OR CI 95\% } \\
\hline & & & & Upper & Lower \\
\hline $\mathrm{RR}$ & 2,001 & 0,034 & 7,399 & 46,935 & 1,166 \\
\hline $\mathrm{SpO}_{2}$ & 4,298 & 0,000 & 73,570 & 394,011 & 13,737 \\
\hline Constant & $-5,071$ & 0,000 & 0,006 & & \\
\hline
\end{tabular}

$\mathrm{SpO}_{2}$, both of the variables show $\mathrm{p}$ value of 0,000 or $<0,25$. Table 6 shows the multivariate analysis result the oxygen saturation is the most dominant variable, compared with respiratory rate variable with a $p$ value of 0,000 and Odds Ratio value $(\mathrm{OR}=73,57)$.

\section{DISCUSSION}

Gender with the most respondents is female of $73,8 \%$. The prior study by Syamsiah, Sitorus, \& Nasution (2011) explains that the gender with the most respondents is male of $54,1 \%$. That condition shows that both female and male (gender) undergo hemodialysis process. Women and men who suffer from chronic renal failure also have the same chance to do hemodialysis process. This is also supported by the research of Syamsiah, Sitorus, \& Nasution (2011), which explains that there is no significant relationship between gender and the obedience of the patients to do hemodialysis process.

This shows that each individual, both female and male, when facing health problem like chronic renal failure, will find out and come to the healthcare provider to solve the problem comprehensively related to the health, in this case, hemodialysis care based on the research result, it shows that the most education achieved by the respondents is Senior High School of 33,9\%. The prior research conducted by Syamsiah, Sitorus, \& Nasution (2011) also explains that the most education achieved by the respondents is Senior High School of 49,7\%. Such condition describes that educational level of somebody can contribute in doing hemodialysis process. This is also supported by the research done by Syamsiah, Sitorus, \& Nasution (2011), which explains that there is a significant relationship between education and obedience in doing hemodialysis process. The result of prior research and the research that has been conducted show that educational level of the respondents contributes in doing hemodialysis process. Such condition also shows that the educational level of an individual contributes to the interest and attitude in doing health maintenance so that the individuals with End Stage Renal Disease will have interest and good attitude in doing hemodialysis process.

The adequate educational level also plays a role to the adequacy of individual's knowledge about therapeutic regimen, health care benefits related to therapy, adequacy of individual's awareness to consider that the health problem that they have is a big problem so that they should do immediate treatment by doing hemodialysis. Adequate education can also play a role to the ability of individuals to determine the right healthcare option in solving the health problem that they have. The research result also shows that the occupational status of the most respondents has is unemployment $(35 \%)$, such condition can contribute in doing the hemodialysis process. Based on the prior research by Sulistini, Yetti, \& Hariyati (2010), it shows that occupational status with most respondents is employment, while in this research; the occupational status with the most respondents is unemployment. The result of prior research and the research that has been conducted show that occupational status of the respondents, both employment and unemployment, contribute in doing hemodialysis process. This condition shows that patients have effective choices to obtain better health condition. Patients with End Stage Renal Disease who do not work have more time to do certain activities especially to fulfill the need of health maintenance by 
doing hemodialysis. The patients with End Stage Renal Disease must provide their time to do hemodialysis therapy twice a week with 4-5 hours per meeting. Whatever the occupational status is, the therapy of HD should be conducted if they patients want to get stable health condition.

The average age of the respondents is 53 years, and that of hemodialysis period is 32 months. Based on Hurlock (1980), age is defined as a unit of time that measures the range of human's life calculated since they were born until the time of the calculation. This research is supported by the research of Septiwi, Yeti, Gayatri (2011) that states that the average age of the respondents with hemodialysis is 50,4 years. Hurlock (1980) explains that the age of 40-60 is the middle-aged adults, and in this age, there is a decrease of physical ability. The age of someone will influence the function of the organ in the body. The category of age in this research has the similarity with the research by Septiwi, Yeti, Gayatri (2010) which is in middle-aged adults stage. Approaching older adults stage, all body organs will have a decrease in their functions, and the filtration ability of kidney will also decrease by $50 \%$ (Sherwood, 2012). This condition will trigger various complaints in urinary system like the feeling of incomplete bladder emptying and the feeling of straining when urinating. Such situation can be the initial sign of the problem in the urinary system and kidney function. Hemodialysis process is an intervention that must be conducted routinely by the patients for the rest of their lives so that it can be stated that patients with hemodialysis are in the category of the end of life care patients, this is because ERSD is categorized as a terminal illness. In the rest of their lives, the patients must be willing to adapt this routinely, twice a week, 4-5 hours of hemodialysis process (Jablonski, Chonchol, 2012). Various complaints might occur when the patients conduct hemodialysis process. However this therapy cannot be stopped since this therapy does not function to cure the disease, but to lengthen the life expectancy of the patients (Kronenberg, 2009). The family should know such condition so that when living the rest of their lives, the patients with hemodialysis therapy will not easy to give up. Table 1.2 explains that the average period of hemodialysis conducted by the patients is 32 months. The research by Septiwi, Yeti, Gayatri (2010) also states that the average hemodialysis period is 19,1 months. The patients with hemodialysis are patients with the category of the end of life care; the therapy given is not intended to heal the patients but to lengthen the life expectancy. If the hemodialysis therapy is conducted routinely based on the schedule of the therapy that has been determined, then the patients can still be productive in living their life, just like the patients who have done hemodialysis for 120 months. Until now, there is no research that can make sure how long the patients with chronic renal failure (ESRD) can survive by doing hemodialysis therapy. However, some research results refer to the evidence that if the patients conduct the hemodialysis process routinely then the life quality is not different from the healthy persons. In addition, it can also influence to the adequacy of the hemodialysis process identified by there is no complaint and complications both in inter-dialysis and intradialysis; it also shows the examination result of the urea and creatinine that is relatively stable in normal range (Nurcahyati, Yetti\&Sabri, 2011; Dewi, Malawat \& Hariyati, 2010).

In this research, $\mathrm{SpO}_{2}$ is measured by using portable pulse oximetry. The pulse oximetry is placed in one of the patients' fingers in which the extremity is not used as the hemodialysis insertion place. $\mathrm{SpO}_{2}$ is the measurement result of the saturated oxygen level as oxyhemoglobin in the blood; pulse oximetry can be used to identify the $\mathrm{SpO}_{2}$ of the patients with the measurement unit of percentage or $6,6 \%$ (Sherwood, 2012). In adult patients, $\mathrm{SpO}_{2}$ is stated to be normal if the measurement result shown by pulse oximetry is in the range of $95-100 \%$ (Kozier, Berman, Snyder, 2010). The research result that has been conducted and the theories show that the patient conducting hemodialysis process have the adequate oxygen level in blood, so it gives positive influence to the tissues in the body. The adequate oxygen perfusion in the patients who will conduct hemodialysis 
process is the good start to do intradialytic process. In intradialytic process, an amount of blood will be cleaned in the hemodialysis machine, and for a moment the body will get homeostatic disruption and imbalance of electrolyte liquid. The result of the research that has been done shows that $66,7 \%$ of the respondents have a normal respiratory rate. The theory states that respiratory rate or breathing frequency or the speed of breathing is the indicator to identify the ability of the pulmonary ventilation per minute, which is commonly observed by observing the rise of the breathing muscles around the chest or abdomen, then calculating the time reference in the watch, stop watch or respiratory rate timer, the measurement unit of respiratory rate is times per minute ( $\mathrm{x} / \mathrm{mnt}$ ) (Kozier, Berman, Snyder, 2010). The result of the research that has been done and the theories show that the ability of individual's ventilation, through observation of the rise of breathing muscle around the chest and abdomen, is adequate per minute, before the patients do the hemodialysis process. Respiratory rate can also describe the situation of oxygenation process of the lungs to all body parts, if the oxygen level in the blood is adequate, then the respiratory rate is in normal range, however, if the oxygen level decreases then the lungs will do breathing compensation by increasing respiratory rate, so that the oxygen supply to the tissues if fulfilled (Yuan, Drost, Mclvor, 2013). The research result and the theories show that the oxygenation process, signed by oxygen supply and carbon dioxide emission through one-time inspiration and expiration of the patients who will do hemodialysis process, is adequately done. Such result signifies that the respondents are ready, in terms of their respiratory rate, to conduct hemodialysis process. The adequate respiratory rate can contribute to the distribution of oxyhemoglobin to the tissue so that it can give positive impact to the patients doing hemodialysis (Chaignon, Chen, Tarazi, Bravo, Nakamoto, 2012). Prior research result shows that there is a significant relationship between Hb level and RR (Sutini, Nurhaeini, $\&$ Besral, 2011). The result of the research that has been done and the result of prior research show that the patients with hemodialysis give impacts to the oxyhemoglobin level change so that it can influence to the RR too. The result of the research that has been done shows that almost the entire respiratory rate is in normal condition, and it means that the oxyhemoglobin level of the patients with hemodialysis is in adequate condition. This also shows that hemodialysis therapy done by patients with ESRD provides adequate contribution to the breathing functions especially the function of the lungs, in which the rise of the lungs is still adequate so that the patients can survive in long enough life of span (Lindholm, Luttropp, Carrero, Witasp, Stenvinkel, Nordfors, 2012). The ability of the pulmonary ventilation can be influenced by some factors like the cleanliness of the windpipe, the adequacy of the center neural system especially breathing center, the ability to breathe muscle and oxygen transport condition in the blood (Sherwood, 2012). The hemodialysis patients who show the quick RR response and look suffocated when they first come to the hospital need to get examination whether they consume more liquid or no, since the liquid accumulation in the body, especially in the abdomen, will disrupt the breathing muscle ability around the abdomen and force the lungs to increase the ventilation ability.

The patients with hemodialysis have the risks of oxygen transport interference in blood during hemodialysis process, and therefore the nurses must observe the readiness of the pulmonary ventilation ability of the patients before they do hemodialysis process. The nurses can examine such condition by conducting an accurate examination of the $\mathrm{RR}$ and other signs of oxygen transport interference like cyanosis or capillary refill condition. If before the hemodialysis process, the patients show suffocation response and increasing RR from the normal range, the patients are suggested to be calm and to take a rest first, and also can be given oxygen supply. The research result also shows that almost all respondents do not experience intradialytic nausea-vomiting occurrence which is of $93,4 \%$. Physiologically, nausea is a response to the uncomfortable feeling of the body coming from the back of esophagus or epigastrium 
and around the stomach signified by pale face, reddish face, tachycardia, cold sweat and much saliva due to emetogenic agents exceeding the body adaptation (Sherwood, 2012). Vomiting is also explained by Sherwood (2012), which is the occurrence of muscle contraction of the stomach and abdomen that will trigger the food expulsion from the digestion system, due to the nausea response that exceeds the limitation of the body adaptation. Vomiting also occurs due to the stimulation in lateral medulla area (Manley, 2015). Nausea and vomiting occur simultaneously (Navari, 2016). Nausea and vomiting conditions that are examined in this research cannot be separated one to another. In this research, intradialytic nausea and vomiting are examined an hour after the hemodialysis machine works, by asking directly to the patients whether they have nausea and vomiting complaints or no.

Suri, Lindsay, Biebe, Pisoni, Garg, Austin (2013), explains that intradialytic nausea-vomiting can be caused by the high of urea and creatinine level, the high speed of hemodialysis, and the imbalance of the liquid and electrolyte that occur during hemodialysis process. Such condition shows that the condition in the intradialytic stage can be considered as an emetogenic condition and become the stimulation to the lateral medulla part of the patients with hemodialysis so that the nausea-vomiting response arises. The complaints of nausea and vomiting during hemodialysis need to be examined to avoid the worse impacts of nausea and vomiting, which is dehydration. Nausea and vomiting can affect to dehydration since during vomiting, the patients release an amount of liquid and electrolyte out of the body, and if it takes a long time then the cells in the body cannot do the function well, such condition is indicated by tachycardia, cold sweat, pale and weak (Sherwood, 2012).

Intradialytic nausea and vomiting will be very dangerous if it happens to HD patients because during hemodialysis process the body gets hemostatic disruption and imbalance of electrolyte liquid for a moment. This situation actually aims at releasing the rest of metabolism accumulation in the body due to the ability decrease of kidney filter. If the patients with hemodialysis get nausea and vomiting continuously, then they will experience dehydration and hypovolemic shock risks that might influence to death.

This research shows that 169 respondents with normal $\mathrm{SpO}_{2}$ of $98,2 \%$ do not experience nausea-vomiting occurrence. In this research, $\mathrm{SpO}_{2}$ is measured by using portable pulse oximetry. Lynn \& LeBon (2011), explain that pulse oximetry is a tool used to measure arterial oxyhemoglobin saturation that is not invasive and easy to use. This tool measures the percentage of hemoglobin $(\mathrm{Hb})$ that is saturated with the oxygen (oxyhemoglobin). Kozier, Berman, \& Snyder, (2010), explain that the normal value of $\mathrm{SpO}_{2}$ is $95-100 \%$. Oxyhemoglobin $\left(\mathrm{HbO}_{2}\right)$ is the result of hemoglobin $(\mathrm{Hb})$ and oxygen $\left(\mathrm{O}_{2}\right)$ forming for tissue perfusion (Sherwood, 2012). During hemodialysis process, an amount of liquid and electrolyte will be released from the body to be cleaned by hemodialysis machine using dialysate liquid. When the process lasts, of course, Oxyhemoglobin $\left(\mathrm{HbO}_{2}\right)$ of the body will decrease too. In hemodialysis process, the body will get hemostatic disruption and imbalance of electrolyte liquid for a while, within 4.5 hours (Penido, 2016). This hemostatic disruption can cause several intradialytic complication complaints of the patients (Mujais \& Ismail, 2011). The complication measured in this researched is a nauseavomiting occurrence. Manley (2015), explains that intradialytic nausea-vomiting can also be caused by hemodialysis period, hemostatic change and the amount of urea released (Itoh, Ezawa, Kikuchi, Tsuruta, Niwa, 2013). Nausea and vomiting during hemodialysis can occur because the condition of saturated oxygen $\left(\mathrm{HbO}_{2}\right)$ is very low, due to oxygen transport interference (Safarudin, Nursasi, Yetti, 2012). The inadequate pathological perfusion condition in gastrointestinal system can affect to the occurrence of nausea and vomiting. Patients with ESRD who conduct hemodialysis routinely have the risks of perfusion interference to the tissue; one of them is in digestion system (Maria, Kohlova, Ribeiro, Rocha-Pereira, Teixeira, Nascimento, et al., 
2014). Due to the lack of oxygen perfusion to the digestion system, then the motility of the intestines will decrease, and thus will affect to the increase of gastric acid level. Such situation is an emetogenic situation in the digestion system. This condition can trigger the nucleus activity of the nerves placed in the lateral medulla oblongata, which eventually will activate Chemoreceptor Trigger Zone (CTZ). Chemoreceptor Trigger Zone is placed on the brain surface and has more blood vessels. CTZ is very sensitive to hemostatic change, like oxyhemoglobin level change. CTZ will directly give a response to vagal nerves and then release emetogenic component from stomach with the help of intra-abdomen pressure increase; this response is called nausea and vomiting (Navari, 2016).

Table 1.4 also explains that 122 respondents who have a normal pre-dialysis respiratory rate of $98,4 \%$ do not experience intradialytic nausea-vomiting complaints. Respiratory rate or the respiratory speed or breathing frequency is observed by detecting the movement of respiratory muscles, like muscles in the chest and in the abdomen; this observation is calculated in one minute using a timer like a watch, stop watch or respiratory rate timer (Lyn \& LeBon, 2011). The speed of the respiratory muscles shows the ability of the pulmonary ventilation in very inspiration and expiration process. The pulmonary ventilation ability can be influenced by some factors, for example, the clean airway, adequacy of central nervous system especially respiratory center, respiratory muscle ability, and oxygen transport condition in the blood (Sherwood, 2012). The normal breathing frequency is $16-20$ times per minute if the breathing frequency is normal, then it can be concluded that the ability of the pulmonary ventilation is adequate. However, it the patients show the problem of quick breathing frequency with short pattern, it shows that the lungs are doing extra compensation to fulfill the need of oxygen in the tissue, when the lungs are no longer capable of doing good compensation, then the breathing frequency will gradually decrease from the normal range (Yuan, Drost, Mclvor, 2013). An amount of electrolyte liquid, including red blood cell of the patients who are doing hemodialysis, will experience imbalance, for a moment.

Ohta, Yasuno, Inomoto, Sasagawa, Nakagawa, Matsuda (2013) states that the blood cells especially red blood cells have the crucial role related to oxygen transport, this is due to $97 \%$ oxygen are in the erythrocyte binding with hemoglobin to form $\mathrm{HbO}_{2}$ and $3 \%$ of oxygen is in plasma. The adequacy of oxygen transport is a good start for the patients who will conduct hemodialysis if at the initial process of hemodialysis the ability of the pulmonary ventilation has been observed and shows the normal result, then it is expected that the patients will not experience intradialytic nausea and vomiting complaints. Such condition is explained in table 1.4 that there is a $p$ value from the Fisher's exact analysis result showing 0,000 results, meaning that there is a very significant relationship between the normal value of pre-dialysis respiratory rate and intradialytic nausea-vomiting occurrence. When the ability of pre-dialysis ventilation is adequate, then the oxygen perfusion to all body will be adequate too, including digestion system. If before the hemodialysis process the patients have shown an increase of breathing frequency, then it means that the ventilation process of the patients is not in adequate condition, so it may affect the oxygen transport of the patients. Intradialytic nausea and vomiting occurrence can be affected due to the hemostatic problem in the blood, the lack of $\mathrm{O}_{2}$ will cause emetogenic reaction in gastrointestinal system, and there will be a very uncomfortable feeling in the throat, hyper saliva, headache complaints, and the push from abdomen to release contents of the gastrointestinal tract, if the patients are not adapted to this situation then it will cause vomiting reaction.

In this research, the pre-dialysis oxygenation status is measured by observing the measurement result of $\mathrm{SpO}_{2}$ and $\mathrm{RR}$ simultaneously. Oxygenation status is the description of the ability of breathing and perfusion in all body (Sherwood, 2012). Lynn \& LeBon (2011), suggest that the oxygenation status examination can employ 
head to toe physical examination or diagnostic examination. The physical examination of oxygenation status of the patients includes inspection, palpation, auscultation, and percussion. Inspection is observation on patients' breathing by observing the rise of the chest, measuring $\mathrm{SpO}_{2}$ and breathing frequency in one minute; palpation is conducted by feeling the vibration power of the breathing sound in the lungs structure; auscultation is conducted by listening to the normal breathing sound and any additional sound, and percussion is identification of the limitation between the heart and the lung. Meanwhile, diagnostic examination can employ chest $\mathrm{x}$-ray examination or sputum examination (Kozier, Berman, Snyder, 2010). The nausea response is one of the pathological condition forms shown by the body when a certain amount of substance interfere digestion system; this response can be indicated by the feeling of unease, headache, and the nausea feeling. If there is somebody who cannot adapt to this response, then the next pathological condition is vomiting or expulsing all or part of the contents of the digestive system that has not been completely digested yet, through the mouth and sometimes through the nose (Manley, 2015). This nausea and vomiting response can cause uncomfortable feeling if it happens during hemodialysis process. One of the causes of nausea and vomiting response is the physical stress due to the imbalance of the liquid during hemodialysis process. A considerable amount of oxygen in red blood cells will be reduced, and this situation will also affect to the hemostatic problem in the blood (Carpi, Donadio, Tramonti, 2016). Such condition is very disturbing if it happens during hemodialysis process and it should get immediate intervention.

Table 1.4 also explains that the data, in which the examination result of predialysis $\mathrm{SpO}_{2}$ and $\mathrm{RR}$ is in the normal range, eventually show no intradialytic nausea and vomiting complaints. After the researchers had conducted simple interview to the respondents with intradialytic nausea and vomiting complaints, they stated that the doctor had given a prescription of antiemetic medicine consumed based on the prescription, if such condition occurs during hemodialysis. The nurses in hemodialysis unit in Panembahan Senopati Hospital also explain that if nausea and vomiting occurs continuously during hemodialysis process, the nurses will reduce the speed of hemodialysis machine gradually and give more isotonic liquid therapy of $\mathrm{NaCl}$ $0,9 \%$, this is done with the expectation that the patients can be in hemostatic condition, as they should. When the condition of the patients experiencing intradialytic nausea and vomiting gradually turns to be normal, then it will be followed by the improvement of their oxygenation status (Dhinakaran \& Lincon, 2014). The improvement of oxygenation status of the patients during hemodialysis process is one of the responsibilities of the nurses in charge of hemodialysis process, and to overcome this problem, a nurse must be sensitive to the change of oxygenation status of the patients and the complaints occurring during hemodialysis process. After the nurses understand the patients' condition well, then they can conduct independent intervention well.

Nekada, Roesli, Ati (2015), in their research entitled "The Influence of Combined Intervention of Deep Breathing and Progressive Muscle Relaxation to Intradialytic Complications in Hemodialysis Unit in Hospital Dr. Soeradjitirtonegoro Klaten" suggest that one of the independent nursing intervention that can be done to overcome intradialytic nausea and vomiting is by complementary therapy innovation, which is the combination of deep breathing relaxation and progressive muscle done in 10 minutes, an hour after the insertion process is completed. This research is an experimental research done to the patients with hemodialysis; patients are taught to do light activities in intradialytic stage through good breathing, and along with that, the patients are also taught to contract and relax several muscle groups, especially muscles in hemodialysis insertion location. Nurses in charge of hemodialysis must be trained first before giving assistance to the patients to do this therapy innovation; this training can optimize the perfusion to the gastrointestinal 
system so that it will reduce the risk of intradialytic nausea and vomiting. The analysis result shows the $p$ value of 0,000 , which means that there is a significant influence on therapy innovation and intradialytic nausea and vomiting occurrence.

Table 1.5 explains that the variables that fulfill the requirements for the multivariate analysis stage are $\mathrm{RR}$ and $\mathrm{SpO}_{2}$, both of the variables show $p$ value of 0,000 or $<0,25$, while for the variable of age, gender, and hemodialysis period are excluded in the multivariate analysis modeling due to the $p$ value of $>0,25$ (Dahlan, 2013). In the research concept framework, those three variables are assumed as confounding variables that may influence to the occurrence of intradialytic nausea and vomiting. However, it doesn't prove to be true that it influence the occurrence of nausea and vomiting shown by the $p$ value of more than 0,05 . This result means that no matter the age of the patients, it does not influence to the occurrence of intradialytic nausea and vomiting, shown by the $p$ value of 0,888 . The age group of the respondents from the range of 21-83 years old does not have a direct impact on the occurrence of intradialytic nausea and vomiting. The gender, both male, and female, do not affect to the occurrence of intradialytic nausea and vomiting; the analysis result of this situation is shown with the $p$ value of 0,145 . The gender of the hemodialysis patients, male and female, is not the determinant whether the patients will experience nausea and vomiting or no. The condition of how long the patients conduct the hemodialysis does not affect to the occurrence of intradialytic nausea and vomiting, and this is shown by the $p$ value of 0,696 . The patients who just start doing hemodialysis process and those with longer hemodialysis period (3-120 months) will not influence the occurrence of intradialytic nausea and vomiting.

The multivariate analysis results in table 1.6 shows that the oxygen saturation is the most dominant variable, compared with respiratory rate variable with a $p$ value of 0,000 and Odds Ratio value $(\mathrm{OR}=73,57)$. It means that the prediction of nausea and vomiting occurrence if the oxygen saturation is abnormal is seventy- three times more than that of with normal oxygen saturation. The multivariate analysis result can be examined further using equation formulations (Dahlan, 2013): $p=1 /\left(1+e^{-y}\right)$; with the equation $\mathrm{y}=($ constant $+\mathrm{a} 1 \mathrm{x} 1+\mathrm{a} 2 \times 2+\ldots+$ aixi). From the equations, it is given that:

1) If the oxygen saturation and respiratory rate are both abnormal, then the probability analysis obtained is $1 /\left(1+\mathrm{e}^{-\mathrm{y}}\right)=1 /\left(1+2,7^{-}\right.$ $(-5,071+2,001+4,298) \times 100 \%=77,20 \%$. This analysis means that if both oxygen saturation condition and pre-dialysis respiratory rate show abnormal measurement then the prediction of nausea and vomiting occurrence is of $77,20 \%$,

2) If it is only respiratory rate that is abnormal, then the probability analysis obtained is $1 /\left(1+\mathrm{e}^{-\mathrm{y}}\right)=1 /\left(1+2,7^{-(-5,071+2,001)}\right) \times 100 \%=$ $4,52 \%$. If it is only the measurement of pre-dialysis respiratory rate that shows abnormal, then the prediction of nausea and vomiting occurrence that might occur in intradialytic stage is of $4,52 \%$.

3) If it is only oxygen saturation that is abnormal, then the probability analysis obtained is $1 /\left(1+\mathrm{e}^{-\mathrm{y}}\right)=1 /\left(1+2,7^{-(-5,071+4,298)}\right) \times 100 \%=$ $31,69 \%$.If it is only the measurement of oxygen saturation that shows abnormal, then the prediction of nausea and vomiting occurrence that might occur in intradialytic stage is of $31,69 \%$.

4) If both only oxygen saturation and respiratory rate are normal, then the probability analysis obtained is $1 /\left(1+\mathrm{e}^{-\mathrm{y}}\right)=1 /\left(1+2,7^{-(-5,071)}\right)$ $\mathrm{x} 100 \%=0,6 \%$. This analysis means that if the measurement of oxygen saturation and respiratory rate shows normal value, then the probability of intradialytic nausea and vomiting occurrence is just of $0,6 \%$.

From the description of multivariate analysis above, the examination of pre-dialysis oxygenation status of the patients, especially $\mathrm{SpO}_{2}$ and RR eventually can facilitate the nurses to anticipate the occurrence of intradialytic nausea and vomiting. Both of the examinations of pre-dialysis oxygen status have the chance to identify the risk of intradialytic nausea and vomiting occurrence shown in table 1.5 that the $p$ values of both variables are $<0,25$. However, in the further 
analysis, it can be seen that the $\mathrm{p}$ value of $\mathrm{SpO}_{2}$ $(0,000)$ shows more dominant result than RR $(0,034) . \mathrm{SpO}_{2}$ is the way to measure oxygen level that is saturated in the blood, while the respiratory rate is to the measurement method of oxygenation status through observation in pulmonary ventilation process. $\mathrm{SpO}_{2}$ is measured using pulse oximetry, while the respiratory rate is measured using time unit of a minute in observation in inspiration and expiration processes through the movement of the muscles around respiratory organs which are muscles in the chest and in the abdomen. The measurement of respiratory rate can be done using a watch, stopwatch, or respiratory rate timer (DeLaune, \& Ladner, 2011). Hemodialysis nurses in Panembahan Senopati Hospital in Bantul have not conducted an examination of the pre-dialysis oxygenation status. Before conducting the hemodialysis process, the patients were asked to weigh themselves; this is done as the QB reference that will be arranged during hemodialysis process. The next examination conducted in intradialytic stage is checking vital signs, for example, blood pressure, pulse rate, and breathing frequency. Besides, the patients would also be asked whether they experienced complaints during hemodialysis process. At the final stage, which is post-dialysis, the patients would be asked to weigh again.

This research result shows that predialysis $\mathrm{SpO}_{2}$ has more dominant impacts to cause intradialytic nausea and vomiting response, compared with the measurement of respiratory rate, thus, hemodialysis nurses would be better to be able to do an examination on pre-dialysis oxygen saturation and read the meaning of the measurement result. The measurement result of $\mathrm{SpO}_{2}$ can be seen in the pulse oximetry screen, and the measurement unit is in the form of a percentage. By using the measurement result of $\mathrm{SpO}_{2}$, the nurses can get clearer illustration about the oxygen condition in the blood of the patients who will conduct hemodialysis process and anticipate the occurrence of intradialytic nausea and vomiting. If in predialysis stage, the measurement of $\mathrm{SpO}_{2}$ shows abnormal response and the patients seem to have problems with the oxygen perfusion, for example, suffocation, cyanosis or bluish, then the nurses can give additional oxygen supply first before doing hemodialysis insertion process (Ito, Yamada, Ueda, Goto, Miyazawa, Ookawara, 2015). From the measurement result of oxygen saturation of the patients before hemodialysis, the nurses can also determine the right intervention to avoid intradialytic nausea and vomiting response, one of them is by suggesting warm water to drink. The warm water consumed can help the vasodilatation of the blood vessel, so that the oxygenation perfusion in the blood and the digestion system run well, and help to improve the intestinal motility function and is able to reduce the risk of nausea and vomiting, especially for the patients with hemodialysis process (Kozier, Berman, Snyder, 2010). The complete examination of pre-dialysis oxygenation status can help the nurses to give a description of the perfusion adequacy of the patients.

\section{Research Limitations}

The sampling technique in this research is total sampling since the researchers would like to see overall condition of the pre-dialysis oxygenation status of the patients and nausea and vomiting complaints that might occur in intradialytic stage. The total patients of hemodialysis process in Panembahan Senopati Hospital in Bantul are 198 persons; however there are some respondents who refuse it, and thus the number of the total respondents is 183.

\section{CONCLUSION}

The pre-dialysis examination of oxygen status conducted in this research shows the evidence that the oxygenation status in the form of oxygen saturation and pre-dialysis respiratory rate play the roles in the occurrence of nausea and vomiting. The variable of age, gender, and hemodialysis period eventually do not prove as confounding variables that might influence to the occurrence of intradialytic nausea and vomiting. The patients with abnormal oxygen saturation are predicted to have seventy-three more chances 
of getting intradialytic nausea and vomiting occurrence compared with the patients with normal oxygen saturation. If the oxygen saturation and pre-dialysis respiratory rate are abnormal, then the chance of intradialytic nausea-vomiting occurrence is $77 \%$. If the pre-dialysis respiratory rate (only) is abnormal, then the chance of intradialytic nauseavomiting occurrence is $4,5 \%$. If the oxygen saturation (only) is abnormal, then the chance of intradialytic nausea-vomiting occurrence is $31,69 \%$. If both oxygen saturation and predialytic respiratory rate are normal, then the chance of intradialytic nausea-vomiting occurrence is $0,64 \%$.

This research result is expected to become the reference for the nurses and nursing students who are conducting practices in hemodialysis rooms in observing the predialytic oxygenation status in the form of oxygen saturation and respiratory rate so that intradialytic nausea and vomiting occurrence can be anticipated. Nurses who are doing healthcare treatment in hemodialysis room are expected to measure the oxygen saturation and respiratory rate accurately. This research is also expected to give input to those who are responsible for managing hemodialysis room in the procurement of portable pulse oximetry to help the examination of oxygen saturation. If in pre-dialysis examination the result of the oxygen saturation of the patients is abnormal, then the nurses can collaborate with the medical healthcare to give additional oxygen therapy and suggest the patients to take a rest for a while before vascular insertion is done. Hemodialysis nurses can facilitate the oxygen perfusion during hemodialysis process by conducting a nursing's independent intervention, which is the combination of deep breathing relaxation and progressive muscle during hemodialysis, to prevent intradialytic nausea and vomiting occurrence. (PDPI 2011; Notoatmodjo 2003)

\section{REFERENCES}

Jolla, L., 2001. Stimulation of Glucose Transport by AMP-activated Protein Kinase via Activation of p38 Mitogenactivated Protein Kinase *. The Journal Of Biological Chemistry, 276(44), pp.41029-41034.

Kusnanto, 2011. Pengembangan Model Self Care Management-Holistic Psychospiritual Care Terhadap Respon Holistik Penderita Diabetes Melitus Tipe 2. Universitas Airlangga.

Notoatmodjo, S., 2003. Metode Penelitian Kesehatan dan Ilmu Perilaku Kesehatan, Jakarta: Rineka Cipta.

PDPI, 2011. Pedoman Penatalaksanaan TB (Konsensus TB). Perhimpunan Dokter Paru Indonesia, pp.1-55. 